\title{
Democratic Control of the Armed Forces, the OSCE Code of Conduct, and the Case of Latvia
}

\author{
Janis Karlsbergs ${ }^{1}$
}

This article will be devoted to a theme that is becoming increasingly topical in politico-military discussions. Today we are observing the situation that it is no longer sufficient to share the values and principles of contemporary democracies, such as free elections, respect for human rights, self-determination, the rule of law, and so forth as expressed in the Helsinki Final Act and the Paris Charter. Events in the world around us remind us that we must also consider ways to implement these values in everyday life. In order to achieve this, we must admit, at least partly, the necessity of going beyond the principle of non-intervention in internal affairs and must open ourselves up to discussions about domestic jurisdiction relating to matters of security and defense.

Some of these principles, such as common markets, open and democratic societies, and human rights, are subjects of discussion in many international forumsthe European Council, the OSCE, the UN, the EU, and even NATO-and often shape the headlines in newspapers. However, some issues are covered less frequently although they remain very important even within Europe. One particular subject that emerges as a rich source of enquiry is the role of armed forces and their relationship with civil society, particularly during conflict situations. While this is only one part of the broader concept of building a modern society, it is an essential component. It is commonly accepted that tasks and responsibilities should be strictly divided between civil and military authorities, but where exactly should the line dividing the two domains be drawn?

The aim of this article is to outline the basic features of the distribution of power and responsibilities between the civil and military authorities in Latvia. This can provide some insights into how to properly structure the armed forces under democratic control, how to formulate their tasks according to local needs, how to develop a legislative framework, and how to avoid the appearance of "warlords" or uncontrolled armed institutions that threaten the democratic fabric of state and society. These and many other questions spring to mind when one thinks about the subject, but it is not my intention to provide elaborate answers. Rather, I hope to supply some "food for thought" to stimulate further discussion on the adequacy of democratic control of the armed forces in Latvia. The OSCE Code of Conduct on Politico-Military Aspects of Security will serve as an organizing

\footnotetext{
${ }^{1}$ Janis Karlsbergs is with the Latvian Delegation to the OSCE. The views expressed in this article are those of the author, and do not necessarily represent the official position of any Latvian institution.
} 


\section{THE QUARTERLY JOURNAL}

device for my presentation of the Latvian case. In the first part of the article, I will present a historical background of the birth of the Latvian National Armed Forces, and in the second part, I will outline the existing legislative framework in the light of the Code of Conduct.

\section{Historical Background}

When examining the subject of democratic control of the armed forces in Latvia, one cannot avoid looking at the historical background, and this is not said simply to draw attention to historical injustices. First, it is quite typical for any Latvian to start every discussion with a history lesson and, second, in order to understand the present, we must try to understand the past. It is vital to trace the way views and perceptions have been influenced by historical events and how the civil-military relationship has evolved.

Looking back in history, Latvians have been living under the rule of foreign masters and serving in alien armies for centuries. Only in 1918, after the collapse of Czarist Russia and the end of World War I, did Latvia became a free country. During its first period as an independent republic, from 1918 to 1940, Latvia grew and prospered, playing its own role in the European economy and community. Latvia was an active member of the international system and enjoyed a standard of living comparable to that of other prosperous smaller European nations. It was during this period that, for the first time in the nation's history, armed forces were established to serve Latvian interests.

Unfortunately, this period of self-determination did not last long. As a consequence of the infamous Molotov-Ribbentrop Pact, signed in 1939 between Nazi Germany and the Soviet Union, Latvia was occupied by Soviet troops in 1940 and then forcibly annexed by the Soviet Union. Latvia's political and military leaders were either summarily executed or deported to the slave labor camps in Siberia. Insufficient and inadequate weapons, lack of military co-operation with its Baltic neighbors, and the decision by President Karlis Ulmanis not to oppose the invading Soviet forces in 1940 brought unspeakable disaster to the nearly 20,000-strong Latvian armed forces and the whole Latvian nation. German forces advancing into Russia drove out the Soviets in 1941, and Latvia was then administered as part of the conquered "Ostland" territories. Many men were forced to serve both the Fascist and Communist regimes, which employed them without regard for human life. More than 200,000 Latvians, like other inhabitants of countries occupied by the Fascists and Communists, were forced to serve in the occupying armies. Many lost their lives in battle and, tragically, even fought each other on opposing sides. At the end of World War II the Soviet Union re-occupied Latvia. Massive deportations followed, with the largest taking place in 1949 when approximately 43,000 people were sent to the Siberian camps. As a result of the Soviet deportations, war losses, and refugees fleeing the country, Latvia lost nearly one third of its total population. 
The Soviet army provided only a negative experience with the military for Latvians during the Soviet regime. Enrolled at the age of 18, young Latvians were mostly sent far away from their native country, obliged to use a foreign language in their military service, and had little or no motivation to defend their abstract and extremely huge "fatherland." The situation became worse with the beginning of the Soviet-Afghan War. Motivation to serve in the army fell even lower, and during this period anti-military sentiment became increasingly widespread. Upon independence, it was the legacy of this unfortunate experience and the subsequent deeply-rooted sentiment that Latvia inherited from its Soviet past. Experiences with the Soviet army as well as earlier military history led to the popular view in contemporary Latvian society that the armed forces were either ineffective when facing a formidable external threat or were costly or even dangerous to society. It is only now, eleven years after regaining independence, with significant progress towards NATO membership having been made and successful reform of the armed forces according to Western standards having been achieved, that old perceptions are starting to change and public support for the armed forces is beginning to rise.

Returning to history, with the advent of Perestroika in the USSR, independence once again seemed possible for the Latvian people. In 1991, the Baltic states of Estonia, Latvia, and Lithuania were the first of the former Soviet republics to break away from the USSR and regain their independence. The newly elected representatives of the people adopted the pre-World War II Latvian Constitution and established a parliamentary form of representative democracy, with an independent judiciary and democratic control over the military. In the newly independent Latvia, all governmental agencies, including the Saeima (parliament), began their work with little established organization, a lack of experienced leadership, and rudimentary structures. With the regaining of independence in 1991, all new governmental institutions were deeply concerned with the improvement of national security. It was particularly difficult to develop the armed forces since there were no weapons, no regulations, no defense concepts or even usable military facilities, and there were also few individuals available with appropriate military experience. It was a firm political decision that Latvia (as with other Baltic states) was not a successor state of the Soviet Union and therefore it had nothing to do with the weapons and military infrastructure of the occupying army. Thus the country started building its defense establishment from scratch. Now, looking back eleven years, this still appears to have been the correct decision, as it prevented the state from spending huge amounts of money on maintaining an obsolete infrastructure and employing unnecessary and expensive weaponry. It allowed the leadership of the country to consider the most appropriate and effective ways to use available financial resources for defense as well as to freely choose the type of defense most suitable for the country.

The first military structure, the Zemessardze (National Guard), was formed in 1991 to provide essential military forces for the protection of the newly formed 
Latvian government. This was an organization similar to the National Guard in the United States, whose members were volunteer citizens. Within a year, their numbers reached 16,000 and they served as the nucleus of today's national armed forces. The first law on Zemessardze was passed on 23 August 1991 and provided the Zemessardze with the following main tasks:

- To involve citizens in state defense and ensure public order.

- To ensure combat and mobilization readiness of its units.

- To accomplish legal and military preparedness of home guards.

- To contribute to the establishment of the rule of law.

This law was modified several times in the following years, and by 2002 essential changes had been made. Namely, the Zemessardze has been completely integrated into the structure of the Latvian National Armed Forces (LNAF) as a part of the Land Forces, mainly as reserve units. The set of main tasks was kept the same, but from the perspective of control over the military, a more stringent and explicit chain of command has been implemented. Militarily, it also enhanced the effectiveness of the LNAF, as the Zemessardze used to enjoy somewhat more autonomy before the reforms. Nonetheless, the very fact that the nucleus of the LNAF emerged from a volunteer citizen organization closely associated with the consolidation of independence in 1991 facilitated the erosion of negative views about the role and utility of the armed forces held through much of Latvian society. In the medium term, it also helped to build links between the armed forces and society, but has increasingly become an outdated mode of fostering those ties in the long term. This is because considerations of military effectiveness have also entered the equation, and other tools of shaping public attitudes have been developed -hence the 2002 reforms.

During the first years of independence, several important laws and documents were adopted which defined and regulated the tasks and responsibilities of the LNAF and the Ministry of Defense (MOD), such as the Defense Concept of the Republic of Latvia (23 March 1992) and the State Defense Law or Law on Defense Forces (4 November 1992). On 13 May 1993, the Defense Minister of Latvia issued the Regulations of the Ministry of Defense that established the orders and tasks of this ministry. Detailed attention will only be given here to one of the aforementioned documents, the Defense Concept, since this document contained all the main ideas that were enshrined in the later laws. The Defense Concept was the first conceptual document since the proclamation of independence in which the political and military bases of state defense were laid down. Already at that time the concept of integration into European and global security structures was anticipated, although NATO had not been specified. Another vitally important aspect of the security situation of that time was the presence of foreign troops (from 
the Russian Federation) on Latvian soil, which was regarded as a serious element of insecurity. This document established the first overall structure of a defense management system and formulated the aims, tasks, and composition of the defense forces and other relevant security institutions.

In this first Defense Concept, there was one extremely interesting and important section devoted to a non-military defense system of the state. This section covered not only civil protection, but a remarkable part of it was allocated to peaceful resistance. Peaceful resistance encompassed mass disobedience, sabotage, and other activities against any occupying regime. It has already been mentioned that a strong anti-military sentiment prevailed in Latvian society, and the concept of peaceful resistance serves as one of the explicit manifestations of this sentiment. Since Latvia possessed no weapons at that time, except the arms stocks of the Soviet Militia, peaceful resistance and disobedience were perceived as the only realistic methods to protect Latvia's independence. Paradoxically, the birth of the LNAF must be seen in the context of mass disobedience and peaceful resistance that were seen as necessary to overthrow the Soviet regime. As the Zemessardze and LNAF were created, the idea of peaceful resistance was removed from subsequent Defense Concept documents (1995 and 1999), although it remained rooted in the minds of the people. However, as the defense establishment continues to develop and enjoys more and more support from society, the concept of non-military resistance, still alive in general society, becomes complementary rather than exclusive to the military dimension of defense.

\section{The Code of Conduct and Latvian Legislation}

It must be mentioned that the Code of Conduct on Politico-Military Aspects of Security, adopted in Budapest on 3 December 1994 by the $91^{\text {st }}$ Plenary Meeting of the Special Committee of the OSCE Forum for Security Co-operation, was seen as a symbolic document long awaited in Latvia. In the early 1970s, when the Helsinki process was commenced, Latvia was not the subject of international relations, but this very process slowly initiated peaceful movements, finally ending with the collapse of the Soviet Union and the regaining of independence for the Baltic states.

The Code of Conduct on Politico-Military Aspects of Security was seen as a continuation of the process of consolidating Latvian independence. It reaffirms the validity and common values expressed in the Helsinki Final Act, adding to the Act some new specific traits in the field of security and defense. Therefore, bearing in mind that Latvia was not participating in the Helsinki Process (although it did relate to those behind the Iron Curtain), it was eager to share the values of democratic societies and participate in the new international system. The Code of Conduct ( $\mathrm{CoC}$ ) was, of course, only one of the expressions of this system, but it included such important ideas as the "comprehensive concept of security" as well as the conviction that "security is indivisible and that the security of each is insep- 


\section{THE QUARTERLY JOURNAL}

arably linked to all others." It included the idea that "the security of one state will not be strengthened at the expense of security of other states"; it iterates the principle of sovereign equality - "the right to belong or not to belong to bilateral or multilateral treaties" - and states the determination "not to impose military domination over any other participating state." These and many other principles were fully endorsed by Latvia. From a practical point of view, the implementation of the $\mathrm{CoC}$ did not pose any problems for Latvia, as all of the basic principles were already present in its legislation. Although the $\mathrm{CoC}$ was an excellent expression of responsible and co-operative relations, however, it contains no serious instruments to guarantee the rights of small actors in the case of unfriendly or uncooperative state relations. It is very much a "fair weather" document. Therefore, the $\mathrm{CoC}$ is more like a barometer that allows us to measure the weather conditions of international relations and demonstrates how responsibly member states are implementing their duties with regard to the $\mathrm{CoC}$. The $\mathrm{CoC}$ provides guidelines and general standards rather than a mechanism for compelling states to establish a functioning system of democratic control.

In order to introduce the defense system and the form of democratic control of the armed forces currently in place in Latvia, the questionnaire of the $\mathrm{CoC}$ exchanged annually among the OSCE states will be used, as this most efficiently structures the essential points described in the Code.

Terrorism: The first point of the questionnaire starts with questions related to measures taken in preventing and combating terrorism, in particular participation in international agreements. At first glance it seems that this question has nothing to do with control of the armed forces, but taking a broader approach to the issue we must realize that effective control over all armed forces encompasses all coercive state institutions possessing the means of violence, including internal security forces, paramilitary structures, intelligence services, and the police. The different ways of combating terrorism point to the necessity of not confining the discussion to merely military establishments. As other, not entirely military tools will be employed far more frequently to address the terrorist threat, democratic control and oversight of those tools becomes imperative. Otherwise, the democratic societies and their values can be put at risk by the excesses of the anti-terrorist strategies, which, paradoxically, are designed to protect those societies and values. Thus the dilemma of finding the right balance between security and effectiveness on the one hand and civil freedoms and liberties on the other that manifests itself in civil-military relations also asserts itself in the light of terrorist threats.

After the tragic events of 11 September 2001, this part of the CoC is becoming increasingly important. In the OSCE, there is an ongoing discussion that perhaps a separate questionnaire concerning member state compliance with international agreements and norms to combat terrorism should be established. To this end, Latvia has always condemned terrorism in all its forms and manifestations, whatever the motivation and whoever the perpetrator is. It regards terrorism as a se- 
rious crime, liable to prosecution and punishment or extradition, in accordance with its criminal and other laws. The current criminal law (in force since 1 April 1999) contains a special Article 88 on Terrorism. Up until now, Latvia has signed and ratified six international conventions and is currently undergoing the process of adopting six other international conventions and protocols concerning antiterrorist measures. However, while adopting all these legal measures and crafting anti-terrorist strategies, the Latvian authorities are well aware of the dangers involved in their enforcement by institutions possessing the means of surveillance and legitimate violence. Their effective political control, oversight, and accountability are understood to be essential in ensuring that the democratic fabric of the civil society is not damaged in the pursuit of greater security. Lessons learned in developing democratic control over the military can be drawn upon as a valuable experience in this effort.

The CoC questionnaire deals more specifically with questions of constitutionally established authorities and procedures to ensure effective democratic political control of armed forces, paramilitary forces, internal security forces, intelligence services, and police. A brief glimpse at the security, intelligence, and police apparatus reveals that, at least in terms of legal framework, Latvia has a fairly developed mechanism for political control and oversight. The Law on the National Armed Forces, Article 3, determines that the Security Service of the Parliament and the State President is a component of the National Armed Forces. The national security system also contains three separate intelligence services: the Bureau for the Protection of the Constitution, the Military Counter-Intelligence Service, and the Security Police. The Law on National Security defines the Bureau for the Protection of the Constitution and the Security Police as internal security authorities, and special laws govern their activities. The Military Counter-Intelligence Service is a state authority under the supervision of the Ministry of Defense. The Bureau for the Protection of the Constitution ensures the operational control of the other security services. Politically, the National Security Council exerts control over all these services and the National Security Commission of Parliament exercises parliamentary control over the secret services.

The legal basis for the activities of the police is provided by the Constitution, the Law on National Security Institutions, the Law on Police, the Law on Operational Acts, and other laws and internal regulations, as well as international treaties regulating the protection of national security and economic sovereignty. According to the Law on Police, Article 38, the government, the Minister of Interior, and local authorities control the police within their own area of competence. Also, the Prosecutor in Chief and his authorized public prosecutors ensure the legal responsibility and integrity of the national security institutions, including the police force. All these institutions are also under the national control of the judiciary in accordance with the Law on Operational Acts. A somewhat more controversial issue in the internal debate was the question of paramilitary forces, as this raised 
the question of whether Latvia actually had such forces. The only possible candidate for such status was the Zemessardze, but since they had been fully integrated into the LNAF under a strictly defined and unified command and control system, the conclusion was drawn that Latvia has no paramilitary forces. Still, under the subtitle "paramilitary" it is necessary to mention that the Law on National Armed Forces mandates that, in wartime or in case of emergency, the Security Department of the Bank of Latvia and, in wartime, the Border Guards will be subsumed into the Latvian National Armed Forces.

Democratic Control of the LNAF: Paragraph VII of the Code of Conduct deals with a whole range of issues concerning the democratic political control of the military, effective guidance to the military, measures guarding against accidental or unauthorized use of military means, national planning and decision-making processes, processes for the determination of military posture, and many other substantial elements of democratic governance of the military. The roles of the Parliament, President, and the government will be elaborated first.

The Republic of Latvia has a system of parliamentary democracy based upon free elections every four years. The elected parliament, the Saeima, appoints the government and control as its activities according to Latvia's constitution. The parliament sets the tasks for the armed forces through national legislation. Its prerogatives also include the declaration of war and peace. It determines the peacetime size of the LNAF and confirms appointment and dismissal of the Commander of the LNAF. Parliamentary budget appropriations, accompanied by the parliamentary oversight of the annual budget execution by the MOD, are key control elements. Parliamentary control provides transparency for the budgeting process. Meanwhile, the government has the authority to make decisions concerning the entire organization of national defense within the frameworks set up by the parliament. The MOD formulates and implements the governmental defense policy, while the Minister of Defense is politically responsible to the parliament. The government appoints and dismisses the Commander of the Zemessardze. The President, elected by the parliament, is the Supreme Commander of the LNAF. He grants the service ranks to the officers. The President's responsibilities include announcing the declaration of war (according to the decision of the parliament). In wartime, the President appoints the Commander-in-Chief of the LNAF. The Commander of the LNAF is directly subordinated to the Minister of Defense. The Deputy Commander of the LNAF, in accordance with the ongoing reform of the LNAF, executes operational command over the LNAF. The division of responsibilities is clarified in the Law on the National Armed Forces and in the Law on National Security. Thus, the whole planning of national defense, its management and command and control are ultimately determined within the political decisionmaking process and within the framework set up by the Constitution and legislation. The constitutional and legal framework provides transparency and a clear 
division of power between the President, the parliament, and the government, including the Minister of Defense.

During the last few years, Latvia has made significant progress in harmonizing and improving its defense legislation. The tasks and responsibilities of the authorities or institutions responsible for the national security system, and the principles and procedures of co-ordination, implementation, and control of their activities have been elaborated in the National Security Law. This law defines the division of labor between the military and the civilian leadership and has the necessary transparency to provide the public with a clear view of how the Ministry of Defense conducts its work. The Law on the National Armed Forces stipulates the composition, mission, tasks, management structure, and funding of the National Armed Forces and the chain of civilian control over the armed forces. The parliament has also recently passed the Mobilization Law and the Mandatory Military Service Law. The latter oversees general regulations of military service that determine the responsibilities and rights of a soldier, procurement, and social guarantees, as well as aspects concerning civilian service. The law determines the basic legal, economic, and social provisions for mandatory military service. Its purpose is, if required, to provide a military force through the use of conscription and to involve the citizens of Latvia in the defense of the nation. These laws form the legal basis of a defense system founded in democratic control over the military.

An additional and, of course, important element of the effective civilian control of the armed forces is that an appropriate institution ensures that they act solely within the constitutional framework and only in pursuit of the tasks that they are assigned. The Law on National Armed Forces, Chapter II, Article 6, defines the tasks of the LNAF as follows:

- To maintain and defend the integrity and sovereignty of national territory, territorial waters, and air space.

- To take part in peace support operations according to national laws and international treaties.

- To train military personnel and reserves.

- To help the public in case of threats and emergencies according to the laws.

Other duties can be assigned only with governmental permission. The Minister of Defense supervises the armed forces in the execution of the abovementioned tasks and missions. He/she has appropriate assisting structures to ensure the legality of actions of the armed forces, such as the Inspector General and the Audit Section in the MOD. Apart from this, there are also Military Police under the Commander of the LNAF.

Aside from these rather legalistic tools, the MOD also possesses certain more sophisticated instruments that help to ensure that the military conduct their 


\section{THE QUARTERLY JOURNAL}

business in a way that complies with democratic norms and values as well as with Latvia's international commitments. The International Humanitarian Law (Geneva Conventions and Additional protocols) has been ratified by parliament. In addition, other international rules, conventions, and commitments governing armed conflict have been incorporated into national legal acts. Therefore, the National Defense Academy has established a course on international defense-related legislation, including the International Humanitarian Law, the Code of Conduct on Politico-Military Aspects, and other international rules, conventions, and commitments governing armed conflicts. Thus the education of servicemen has emerged as one of the primary means to inculcate democratic values and respect for them, and to make sure that the conduct of military operations remains within the boundaries of what is deemed acceptable by the democratic Latvian society.

Further attention has been focused on promoting public understanding and support for the armed forces through openness and transparency. Open discussions on their development, transparency in their budget and finances, adherence to established laws and discussions on new concepts, plans, and laws for the armed forces have facilitated public involvement and understanding. In order to achieve transparency in LNAF functions, activities, and expenditures, a practice of reporting to the parliament on state defense policy and the status of the LNAF was introduced in 2000. The annual report, the so-called White Book, is publicly available. A regular detailed explanation of the defense budget is prepared and published annually. It explains to the parliament and the public the utilization of the defense budget. In a similar vein, the principle of public access to official documents has been firmly established in the Constitution. It stipulates the public right to access official documents kept by authorities, including the armed forces. This right is limited only if the documents concern vital aspects of national security, economic and political interests, or information obtained in bilateral Cupertino with other states or international organizations. Within the defense system, the information provided to individuals and the media must be in accordance with the Laws on Publicity of Information, on State Secrets, on National Defense, on the National Armed Forces, on the National Guard, and other governmental rules and military regulations.

However, the basis for close ties between the armed forces, the Zemessardze, and Latvian society in general goes back to the days of the first period of independence. Pride in its own armed forces, which has deep roots in society, formed a bond that exists to this day, in spite of the fierce dislike that the Latvian people had for the army of Soviet occupation. With each additional year, the popularity of the armed forces continues to grow. The "day of open doors" has become a popular event, and now all military units have taken up this practice. Parents of new recruits are invited to observe the oath-taking ceremony and to meet the officers and NCOs responsible for their sons' well-being. During the past year, one of the most popular events was to invite the press to spend the whole day with the troops. 
This proved extremely interesting and was viewed positively by the public. Such activities help the public to understand the Latvian National Armed Forces, their everyday life, and their mission. This understanding fosters trust, confidence, and interaction between society and its armed forces.

\section{Conclusion}

This article, positive as it may be, was not intended to prove that the system of democratic control of the armed forces in Latvia is so perfect and ideal that it cannot be improved. It is still under construction, although it functions rather well. The main principles of democratic control are built into the system, and now the task is to produce more specific regulations explaining laws in a detailed way and to ensure continued compliance with these norms in everyday life. The chain of command and division of responsibilities between the parliament, President, government, Defense Minister, and Commander of the Latvian National Armed Forces are reasonably well defined and fixed in the laws. During the past eleven years, the system has proved itself to be reasonably logical, and no serious incidents or misunderstandings have happened.

However, the youth of Latvian democracy and its armed forces stands both as an advantage and disadvantage. Much has been accomplished during the last decade, but it still occurs that people are not fully aware of their rights and duties. This problem is one more of an administrative and organizational nature and is mostly related to the fact that the legislation has been developing faster than the capacity to appreciate the changes and new developments. There are similar difficulties with the development of the defense system, which often demands new legislation or regulations. In this respect, the last two years were very productive and demanding. Several important laws and regulations were finalized and accepted, such as the Law on Mobilization, the Law on Mandatory Military Service, the Law on Alternative Service, and the Manual of Soldiers' Military Discipline. Changes have been made in the Law on National Armed Forces and the Law on National Security. Without doubt, these changes improve the system by specifying and clarifying the various tasks, but it will take some time to implement them fully. The legislative apparatus, controlling mechanisms, and implementation structures are able to work in close dialogue with each other to find the best solutions to multiple problems, but it takes time before those solutions are finally absorbed into the system. Finally, and related to that, it should be said that there cannot be one universal model of democratic control of the armed forces that can be applied to every state. During the first five years of independence, there were ideas flying around in Latvia about using existing models of other states, but all of them have failed. The most important element is to follow the main principles, but determining exactly how they are incorporated into domestic legislation and everyday practice is the responsibility of each individual state. 